\title{
Specificity of Thermophilic Streptomyces Alkaline Proteinase
}

\author{
Masashi Matsue,* Eiji MaJima and Eiji IChishima** \\ Laboratory of Enzymology and Microbial Chemistry, \\ Tokyo Nōkō University, Fuchu, Tokyo 183, Japan \\ Received March 3, 1982
}

\begin{abstract}
The specificity of highly purified alkaline proteinase B (EC 3.4.21.14) from thermophilic Streptomyces rectus var. proteolyticus was investigated with an oxidized insulin B chain. Hydrolysis of the oxidized insulin B chain in a 4-hr incubation was observed mainly at three peptide bonds $\left(\mathrm{Phe}^{24}-\mathrm{Phe}^{25}\right.$, $\mathrm{Leu}^{15}-\mathrm{Tyr}^{16}$ and $\mathrm{Leu}^{11}-\mathrm{Val}^{12}$ ) and additionally at six others $\left(\mathrm{Leu}^{6}-\mathrm{CySO}_{3} \mathrm{H}^{7}, \mathrm{Gln}^{4}\right.$ $\mathrm{His}^{5}, \mathrm{Leu}^{17}-\mathrm{Val}^{18}$, $\left.\mathrm{His}^{5}-\mathrm{Leu}^{6}, \mathrm{Glu}^{13}-\mathrm{Ala}^{14}, \mathrm{Asn}^{3}-\mathrm{Gln}^{4}\right)$.

Hydrolysis of angiotensin (formerly designated angiotensin II) was observed at the $\mathrm{Tyr}^{4}-\mathrm{Il}^{5}$ bond. Hydrolysis of proangiotension (formerly designated angiotensin I) was observed at the $\mathrm{Tyr}^{4}$ $\mathrm{Ile}^{5}$ and $\mathrm{Phe}^{8}-\mathrm{His}^{9}$ bonds.
\end{abstract}

The extracellular alkaline proteinase B (EC 3.4.21.14), produced by thermophilic Streptomyces rectus var. proteolyticus, a soil microorganism, shows optimal activity at $\mathrm{pH} 10.7$ for milk casein digestion, ${ }^{1)}$ and it possesses a single active serine residue $^{2)}$ and a single thiol group. ${ }^{3)}$

In the present study, the specificity of thermophilic Streptomyces alkaline proteinase B was investigated towards oxidized insulin B chain, angiotensin and proangiotensin.

\section{MATERIALS AND METHODS}

Materials. Crystalline bovine insulin (Lot 24C-3130) was purchased from Sigma Chemical Co. Human angiotensin (Lot 29073) and proangiotensin (Lot 291022) were purchased from the Protein Research Foundation, Osaka. Polyamide layer sheet (Lot 690418) was purchased from the Seikagaku Kogyo Co.

An oxidized insulin B chain was prepared according to the method described previously. ${ }^{4)}$

Streptomyces alkaline proteinase. The alkaline proteinase B was assayed according to the method described previously. ${ }^{5)}$ One katal of alkaline proteinase B was defined as the amount of enzyme which yields the equivalent of $1 \mathrm{~mol}$ of tyrosine per second at $280 \mathrm{~nm}$, using milk casein as substrate at $\mathrm{pH} 8.0$ and $30^{\circ} \mathrm{C}$.

Crystalline alkaline proteinase from Streptomyces rectus var. proteolyticus was the gift of Dr. K. Mizusawa, Kikkoman Corp.

Determination of time course for the hydrolysis of oxidized insulin $B$ chain. The oxidized insulin B chain $(8.75$ $\mathrm{mg}$ ) was dissolved in $12.5 \mathrm{ml}$ of $0.05 \mathrm{M}$ sodium borate buffer, $\mathrm{pH} 8.0$, and incubated for $20 \mathrm{~min}$ with 2.2 nkatal (enzyme/substrate $(\mathrm{e} / \mathrm{s})=1: 1600, \mathrm{~mol} / \mathrm{mol}$ ) of Streptomyces alkaline proteinase at $30^{\circ} \mathrm{C}$. Aliquots $(500 \mu \mathrm{l})$ were withdrawn at various time intervals and mixed with $500 \mu 15 \%$ acetic acid; a ninhydrin assay ${ }^{6)}$ was carried out on these samples. The total numbers of amino groups of the oxidized insulin B chain were determined with a hydrolysate of $6 \mathrm{~N} \mathrm{HCl}$ at $110^{\circ} \mathrm{C}$ for $24 \mathrm{hr}$.

Hydrolysis of oxidized insulin $B$ chain. The oxidized insulin B chain $(7 \mathrm{mg}$ ) was dissolved in $10 \mathrm{ml} 0.18 \mathrm{M}$ $\mathrm{NH}_{4} \mathrm{OH}$, and $2.2 \mathrm{nkatal}(\mathrm{e} / \mathrm{s} ; 1: 1280, \mathrm{~mol} / \mathrm{mol})$ of alkaline proteinase B from Streptomyces was added to the solution, and then the $\mathrm{pH}$ was adjusted to 8.0 with $\mathrm{NH}_{4} \mathrm{OH}$. The mixture was incubated at $30^{\circ} \mathrm{C}$ for $4 \mathrm{hr}$. One drop of concentrated $\mathrm{HCl}$ was added to inactivate the enzyme. The samples of hydrolysate were stored at $-20^{\circ} \mathrm{C}$, and then the frozen digest was lyophilized.

Hydrolysis of angiotensin and proangiotensin. Angiotensin (angiotensin II, $2 \mathrm{mg}, 1.98 \mu \mathrm{mol}$ ) was dissolved in $10 \mathrm{ml}$ of $0.18 \mathrm{M} \mathrm{NH} \mathrm{NH}_{4} \mathrm{OH}$ at 8.0 , and incubated at $30^{\circ} \mathrm{C}$ with $2.5 \mathrm{nkatal}(\mathrm{e} / \mathrm{s} ; 1: 1200, \mathrm{~mol} / \mathrm{mol})$ of Streptomyces alkaline proteinase B for $1 \mathrm{hr}$.

Proangiotensin (angiotensin I, $2 \mathrm{mg}, 1.54 \mu \mathrm{mol}$ ) was dissolved in $10 \mathrm{ml}$ of $0.18 \mathrm{M} \mathrm{NH}_{4} \mathrm{OH}$ at $\mathrm{pH} 8.0$, and incubated at $30^{\circ} \mathrm{C}$ with $2.5 \mathrm{nkatal}(\mathrm{e} / \mathrm{s} ; 1: 968, \mathrm{~mol} / \mathrm{mol})$ of

* Present address: Miyake High School, Miyake Village, Miyake Island, Tokyo 100-12, Japan.

** To whom inquires about this paper should be addressed. 
Streptomyces alkaline proteinase B for $1 \mathrm{hr}$.

Separation of peptides from enzymatic digest. The freezedried digest was dissolved in $50 \mu \mathrm{l} 1 \mathrm{M} \mathrm{NH} \mathrm{NH}_{4} \mathrm{OH}$, and was separated on Toyo filter paper, in the first dimension by high-voltage paper electrophoresis, and in the second dimension by paper chromatography by a method previously described. ${ }^{4)}$ The letters $\mathrm{A}, \mathrm{N}$ and $\mathrm{B}$ refer to acidic, neutral or basic peptides, respectively.

Further purifications of the B-1 and N-3 peptides shown in Fig. 2 were performed on chromatographic procedures with Bio-Gel P-2 $(1 \times 55 \mathrm{~cm})$, respectively. Elution was performed with $0.1 \mathrm{M} \mathrm{NH} \mathrm{NH}_{4} \mathrm{OH}$. The peptide fractions eluted from Bio-Gel P-2 were determined at $230 \mathrm{~nm}$. Further purification of $\mathrm{N}-4$ peptide was performed on DEAE-Sephadex A-25. Gradient elution was performed with $\mathrm{NH}_{4} \mathrm{CO}_{3}$ from $0.1 \mathrm{M}$ to $1 \mathrm{M}$.

Amino acid analysis. Freeze-dried peptides were dissolved in $2 \mathrm{ml}$ of $5.7 \mathrm{~N} \mathrm{HCl}$ and were hydrolyzed at $110^{\circ} \mathrm{C}$ for $24 \mathrm{hr}$. Hydrolysates of peptides were examined with a Hitachi amino acid analyzer, Model 835-30.

Determination of $N$-terminal amino acid of peptides. The $\mathrm{N}$-terminal amino acids of the purified peptides (A-1, A-2, $\mathrm{N}-1, \mathrm{~N}-2, \mathrm{~N}-3 \mathrm{a}, \mathrm{N}-3 \mathrm{~b}, \mathrm{~N}-4 \mathrm{a}$ and B-1a) were determined by the DNP-method of Sanger. ${ }^{7)}$

The N-terminal amino acids of peptides obtained from angiotensin and proangiotensin were determined by the DNS-method. ${ }^{8)}$ The DNS-amino acids were identified by polyamide layer sheet $(7.5 \times 7.5 \mathrm{~cm})$ using the solvent system: $1.5 \% \mathrm{HCOOH}$, and benzene-acetic acid $(9: 1$, $\mathrm{v} / \mathrm{v})$.

Relative rate of hydrolysis. The relative rate of hydrolysis at the $\mathrm{Phe}^{24}-\mathrm{Phe}^{25}$ was calculated from the peptides recovered.

\section{RESULTS}

\section{Hydrolysis of oxidized insulin $B$ chain}

The rate of hydrolysis of the oxidized insulin $B$ chain was examined and the results are shown in Fig. 1. The peptides obtained in 4-hr incubation were isolated and purified as described; a total of twelve peptides were obtained. The strong spots shown in the finger print map (Fig. 2) of the digest from the oxidized insulin $\mathrm{B}$ chain were the acidic peptide A-2, neutral peptides $\mathrm{N}-1, \mathrm{~N}-2, \mathrm{~N}-3$ and the basic peptide B-1. Further purifications of B-1, N-3 and N-4 fractions were performed on chromatographic procedures.

Table I lists the peptides, their amino acid

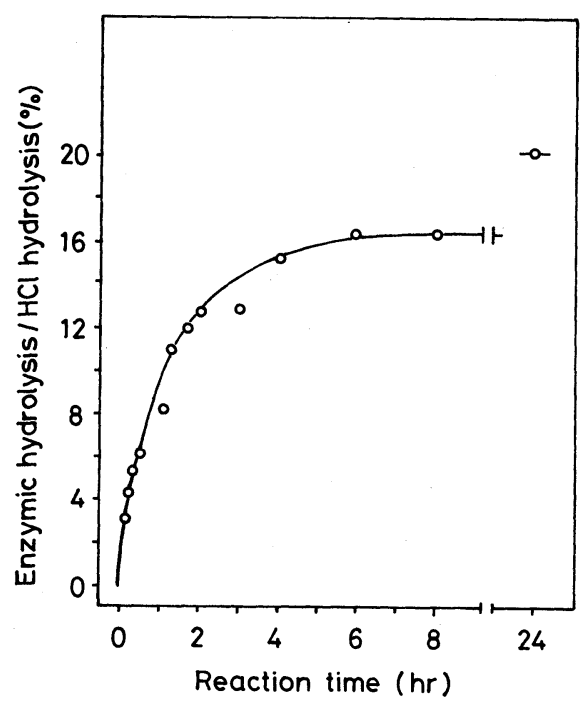

FIG. 1. Time Course for the Hydrolysis of the Oxidized Insulin B Chain by Thermophilic Streptomyces Alkaline Proteinase B.

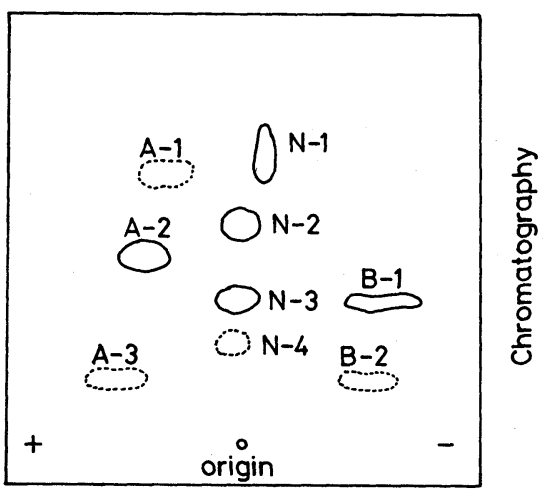

Electrophoresis

FIG. 2. Peptide Map of the Digest of the Oxidized Insulin B Chain by Thermophilic Streptomyces Alkaline Proteinase B.

compositions and recoveries. All of the peptides were readily identifiable from the known sequence of the oxidized insulin B chain. However, the B- $1 \mathrm{~b}$ fraction contained at least two peptides. In the case of $\mathrm{B}-1 \mathrm{~b}$, it was possible to assume the fraction had two peptides, B-1b-1 and B-1b-2, as indicated in Table I. The recovery of the peptide $\mathrm{His}^{5}-\mathrm{Leu}^{6}$ (B-1b2) was not determined, because the presence of a contaminating $\mathrm{B}-1 \mathrm{a}$ peptide in the $\mathrm{B}-1 \mathrm{~b}$ preparation still remained a possibility. A 
Table I. Amino Acid Composition of Peptides from the 4-hr Digest of Oxidized Insulin B

Chain by Thermophilic Streptomyces Alkaline Proteinase B ${ }^{a}$

\begin{tabular}{|c|c|c|c|c|c|c|c|c|c|c|c|c|c|}
\hline \multirow{2}{*}{$\begin{array}{l}\text { Amino } \\
\text { acids }\end{array}$} & \multicolumn{13}{|c|}{ Peptides (residues/molecule) } \\
\hline & A-1 & A-2 & A-3 & $\mathrm{N}-1$ & $\mathrm{~N}-2$ & $\mathrm{~N}-3 \mathrm{a}$ & $\mathrm{N}-3 \mathrm{~b}$ & $\mathrm{~N}-4 \mathrm{a}$ & $\mathrm{N}-4 \mathrm{~b}$ & B-1a & B-1b-1 & B-1b-2 & B-2 \\
\hline $\mathrm{CySO}_{3} \mathrm{H}$ & & $0.8(1)$ & $0.9(1)$ & & & $1.0(1)$ & & $0.5(1)$ & $0.9(1)$ & & & & \\
\hline Asp & & & & & $0.8(1)$ & & $1.0(1)$ & & & & & & $1.0(1)$ \\
\hline Thr & & & & & & & & & & $1.0(1)$ & $1.4(1)$ & & \\
\hline Ser & & & $0.9(1)$ & & & $0.8(1)$ & & & $1.1(1)$ & & & & \\
\hline Glu & $1.0(1)$ & $1.0(1)$ & & & & & $0.9(1)$ & $2.0(1)$ & & & & & $1.0(1)$ \\
\hline Pro & & & & & & & & & & $0.5(1)$ & $0.9(1)$ & & \\
\hline Gly & & $1.8(2)$ & $1.1(1)$ & & & $1.0(1)$ & & $3.6(2)$ & $2.2(1)$ & & & & \\
\hline Ala & $1.0(1)$ & & & $1.0(1)$ & & & & & & $1.0(1)$ & $1.0(1)$ & & \\
\hline Val & $1.0(1)$ & $1.0(1)$ & & & $1.0(1)$ & & $0.8(1)$ & $0.5(1)$ & & & & & $1.0(1)$ \\
\hline Leu & $1.3(1)$ & $1.0(1)$ & $1.0(1)$ & $1.9(2)$ & & $2.0(1)$ & & & $2.0(2)$ & & & $0.6(1)$ & \\
\hline Tyr & & $0.6(1)$ & & $1.0(1)$ & & & & & & $0.9(1)$ & $1.4(1)$ & & \\
\hline Phe & & $0.9(1)$ & & & $0.6(1)$ & & $0.9(1)$ & $1.0(1)$ & & $0.7(1)$ & $1.1(1)$ & & $0.5(1)$ \\
\hline Lys & & & & & & & & & & $1.0(1)$ & $1.3(1)$ & & \\
\hline His & & & $0.7(1)$ & & & $1.0(1)$ & & & $2.0(2)$ & & & $0.4(1)$ & $0.8(1)$ \\
\hline Arg & & $0.9(1)$ & & & & & & $1.0(1)$ & & & & & \\
\hline $\begin{array}{l}\text { Recovery } \\
(\mu \mathrm{mol})\end{array}$ & 0.278 & 0.862 & 0.460 & 0.188 & 0.142 & 0.101 & 0.639 & 0.091 & 0.228 & 0.466 & nd & nd & 0.106 \\
\hline $\begin{array}{l}\text { N-Terminal } \\
\text { amino acid }\end{array}$ & Val & Tyr & $\mathrm{nd}^{*}$ & Ala & Phe & Leu & Phe & Val & nd & Phe & Phe & nd & nd \\
\hline $\begin{array}{l}\text { Suggested } \\
\text { segment }\end{array}$ & $12 \sim 15$ & $16 \sim 24$ & $7 \sim 11$ & $14 \sim 17$ & $1 \sim 3$ & $6 \sim 11$ & $1 \sim 4$ & $18 \sim 24$ & $5 \sim 11$ & $25 \sim 30$ & $25 \sim 30$ & $5 \sim 6$ & $1 \sim 5$ \\
\hline
\end{tabular}

* nd, not detected.

a The values in parentheses denote the theoretical number of residues of a given amino acid in the peptide. 

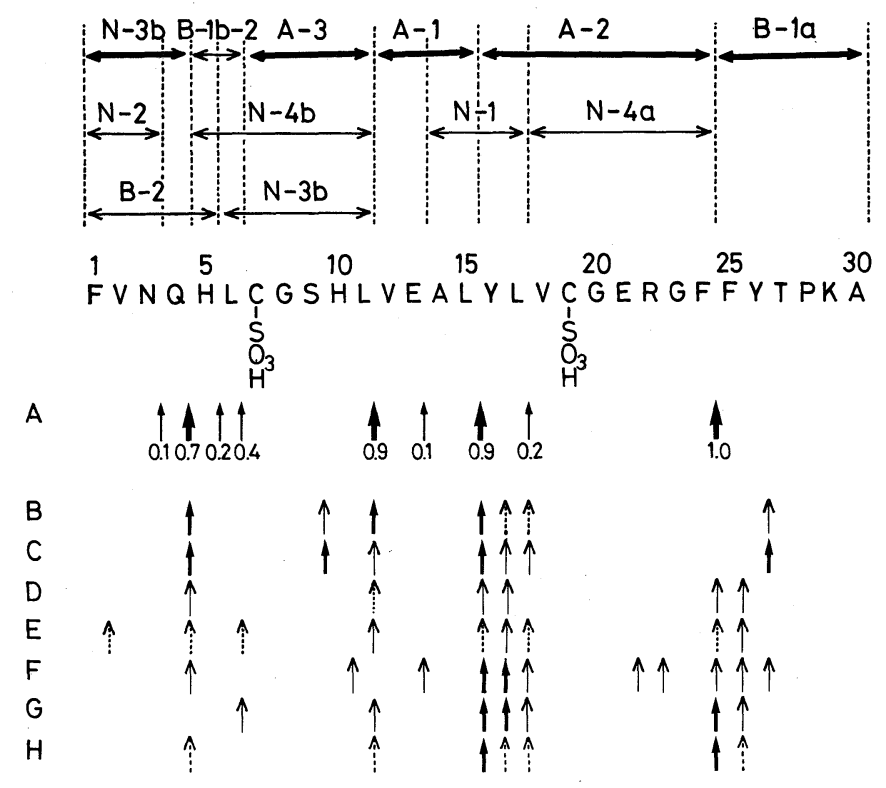

FIG. 3. Summary of the Specificity of Thermophilic Streptomyces Alkaline Proteinase B towards the Oxidized Insulin B Chain.
Abbreviations of amino acids are alphabetical. The perpendicular arrows indicate the bond split and relative rate of hydrolysis at the $\mathrm{Phe}^{24}-\mathrm{Phe}^{25}$ bond. Thick arrows indicate major sites; thin arrows, minor sites. Horizontal arrows indicate the peptides obtained.
A: Thermophilic Streptomyces rectus alkaline proteinase B, 4-hr incubation at $\mathrm{pH} 8.0$ and $30^{\circ} \mathrm{C}(\mathrm{e} / \mathrm{s}, 1: 1260$, $\mathrm{mol} / \mathrm{mol}$ ).
B: Subtilisin Carlsberg, ${ }^{11)}$ 2-hr incubation at $\mathrm{pH} 8.0$ and $30^{\circ} \mathrm{C}(\mathrm{e} / \mathrm{s}, 1: 980, \mathrm{w} / \mathrm{w})$.
C: Subtilisin Novo, ${ }^{11)} 2$-hr incubation at $\mathrm{pH} 8.0$ and $30^{\circ} \mathrm{C}(\mathrm{e} / \mathrm{s}, 1: 1170$, w/w).
D: Streptomyces fradie proteinase type III, ${ }^{12)}$ at $\mathrm{pH} 9$ and room temperature.
$\mathrm{E}$ : Streptomyces griseus alkaline proteinase $\mathrm{C},{ }^{13)} 2$-hr incubation at $\mathrm{pH} 9.2$ and $30^{\circ} \mathrm{C}$ with a carboxymethy- lated B-chain of insulin.
F: Steptomyces alkalophilic keratinase, ${ }^{14)} 24-\mathrm{hr}$ incubation at $\mathrm{pH} 11.6$ and $37^{\circ} \mathrm{C}$.
$\mathrm{G}$ : Cathepsin $\mathrm{G}^{10)}$ 4-hr incubation at $\mathrm{pH} 8.5$ and $37^{\circ} \mathrm{C}$, (e/s, $1: 1000$, w/w).
$\mathrm{H}$ : Saccharomyces cerevisiae proteinase $\mathrm{B},{ }^{15)} 6-\mathrm{hr}$ incubation at $\mathrm{pH} 7.2$ and $25^{\circ} \mathrm{C}$ at ratio $500: 1$ (mol insulin $\mathrm{B}$ chain/mol proteinase B).

summary of the specificity of Streptomyces alkaline proteinase B is shown in Fig. 3.

\section{Hydrolysis of angiotensin and proangiotensin}

When angiotensin was digested with Streptomyces alkaline proteinase B for $1 \mathrm{hr}$, the products could be resolved into three spots (a-1, a-2 and a-3) by high-voltage paper electrophoresis and paper chromatography. The digestion products of angiotensin were subjected to amino acid analysis. The results are shown in Table II. The peptide bond that had been hydrolyzed by Streptomyces alkaline proteinase B was the $\mathrm{Tyr}^{4}-\mathrm{Ile}^{5}$ bond in angiotensin.
When proangiotensin was digested with Streptomyces alkaline proteinase for $1 \mathrm{hr}$, the products could be resolved into four spots ( $p$ $1, \mathrm{p}-2, \mathrm{p}-3$ and $\mathrm{p}-4)$ by high-voltage paper electrophoresis and paper chromatography. The peptide bonds that had been hydrolyzed by Streptomyces alkaline proteinase B were the $\mathrm{Tyr}^{4}-\mathrm{Ile}^{5}$ and $\mathrm{Phe}^{8}$-His ${ }^{9}$ bonds in proangiotensin. The specificities of the alkaline proteinase $\mathrm{B}$ towards angiotensin and proangiotensin are shown in Fig. 4.

\section{DISCUSSION}

Major cleavage sites at $\mathrm{Phe}^{24}-\mathrm{Phe}^{25}, \mathrm{Leu}^{11}$ - 
Table II. Amino Acid Composition of Peptides Obtained from Angiotensin and

Proangiotensin by Thermophilic Streptomyces Alkaline Proteinase B ${ }^{a}$

\begin{tabular}{|c|c|c|c|c|c|c|c|}
\hline \multirow{3}{*}{$\begin{array}{l}\text { Amino } \\
\text { acids }\end{array}$} & \multicolumn{7}{|c|}{ Peptides (residues/molecule) } \\
\hline & \multicolumn{3}{|c|}{ Angiotensin } & \multicolumn{4}{|c|}{ Proangiotensin } \\
\hline & $a-1$ & $a-2$ & $a-3$ & $\mathrm{p}-1$ & $\mathrm{p}-2$ & $\mathrm{p}-3$ & $\mathrm{p}-4$ \\
\hline Asp & $1.0(1)$ & $1.0(1)$ & & $1.0(1)$ & $1.0(1)$ & & \\
\hline Pro & $1.2(1)$ & & $1.4(1)$ & $1.2(1)$ & & $1.4(1)$ & \\
\hline Val & 0.9 (1) & $1.0(1)$ & & $1.1(1)$ & $1.0(1)$ & & \\
\hline Ile & $1.0(1)$ & & $1.0(1)$ & $1.0(1)$ & & $1.0(1)$ & \\
\hline Leu & & & & & & & $1.0(1)$ \\
\hline Tyr & $0.9(1)$ & $1.0(1)$ & & $0.8(1)$ & $1.0(1)$ & & \\
\hline Phe & 0.9 (1) & & $1.0(1)$ & $1.0(1)$ & & $1.0(1)$ & \\
\hline His & $0.8(1)$ & & 0.9 (1) & 0.9 (1) & & & $0.7(1)$ \\
\hline Arg & $1.0(1)$ & $1.1(1)$ & & $1.0(1)$ & $1.1(1)$ & $1.0(1)$ & \\
\hline $\begin{array}{r}\text { Recovery } \\
(\mu \mathrm{mol})\end{array}$ & 0.388 & 0.422 & 0.499 & 0.100 & 0.629 & 0.559 & 0.632 \\
\hline $\begin{array}{l}\text { N-Terminal } \\
\text { amino acid }\end{array}$ & & Asp & Ile & Asp & Asp & Ile & His \\
\hline $\begin{array}{l}\text { Suggested } \\
\text { segment }\end{array}$ & $1 \sim 8$ & $1 \sim 4$ & $5 \sim 8$ & $1 \sim 8$ & $1 \sim 4$ & $5 \sim 8$ & $9 \sim 10$ \\
\hline
\end{tabular}

a The values in parentheses denote the theoretical number of residues of a given amino acid in the peptide.

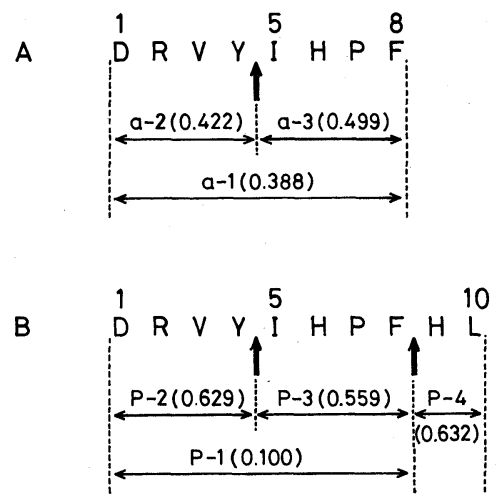

FIG. 4. Specificity of Thermophilic Streptomyces Alkaline Proteinase B towards Angiotensin (A) and Proangiotensin (B).

The values in parentheses denote the recovery ( $\mu \mathrm{mol})$ of peptides. Arrows indicate the bond split.

$\mathrm{Val}^{12}$ and $\mathrm{Leu}^{15}-\mathrm{Tyr}^{16}$ in the oxidized insulin B chain in 4-hr incubation with proteinase were observed. When proangiotensin or angiotensin were digested with the proteinase, the $\mathrm{Tyr}^{4}-\mathrm{Ile}^{5}$ was readily hydrolyzed. Using the numbering system of Schechter and Berger, ${ }^{9)}$ the peptide bonds $\left(\mathrm{P}_{1}-\mathrm{P}_{1}{ }^{\prime}\right)$, which have hydrophobic amino acids in the $P_{1}$ and $P_{1}^{\prime}$ positions, are preferentially cleaved by the proteinase.

Additional cleavages of the bonds, $\mathrm{Gln}^{4}$ $\mathrm{His}^{5}, \mathrm{Leu}^{6}-\mathrm{CySO}_{3} \mathrm{H}^{7}, \mathrm{Leu}^{17}-\mathrm{Val}^{18}, \mathrm{His}^{5}-\mathrm{Leu}^{6}$, $\mathrm{Gln}^{13}-\mathrm{Ala}^{14}$ and $\mathrm{Asn}^{3}-\mathrm{Gln}^{4}$ in the oxidized insulin B chain in 4-hr incubation, were also observed. These results suggest that the proteinase preferentially cleaved the oxidized insulin B chain on the calboxyl side of leucine.

When proangiotensin was digested with the proteinase, the $\mathrm{Phe}^{8}-\mathrm{His}^{9}$ bond also hydrolyzed. The result suggests that the proteinase requires oligopeptide to have the $\mathrm{P}_{2}{ }^{\prime}$ position.

The cleavage sites at $\mathrm{Leu}^{6}-\mathrm{CySO}_{3} \mathrm{H}^{7}, \mathrm{Leu}^{11}$. $\mathrm{Val}^{12}$, Leu ${ }^{15}-\mathrm{Tyr}^{16}$, Leu ${ }^{17}-\mathrm{Val}^{18}$ and $\mathrm{Phe}^{24}$ $\mathrm{Phe}^{25}$ in the oxidized insulin $\mathrm{B}$ chain by the proteinase were identical with those in the work with cathepsin G. ${ }^{10)}$ The cleavage sites at $\mathrm{Gln}^{4}-\mathrm{His}^{5}, \mathrm{Leu}^{11}-\mathrm{Val}^{12}, \mathrm{Leu}^{15}-\mathrm{Tyr}^{16}$ and $\mathrm{Phe}^{24}$ $\mathrm{Phe}^{25}$ with the proteinase were similar to those reported in the studies of $S$. fradiae proteinase III $^{12)}$ and $S$. griseus alkaline proteinase ${ }^{13)}$ respectively. The cleavage sites at $\mathrm{Gln}^{4}-\mathrm{His}^{5}$, $\mathrm{Glu}^{13}-\mathrm{Ala}^{14}, \mathrm{Leu}^{15}-\mathrm{Tyr}^{16}, \mathrm{Leu}^{17}-\mathrm{Val}^{18}$ and $\mathrm{Phe}^{24}-\mathrm{Phe}^{25}$ by the proteinase were similar to those reported in the studies of Streptomyces alkalophilic keratinase. ${ }^{14)}$ 
Major cleavage sites at $\mathrm{Leu}^{15}-\mathrm{Tyr}^{16}$, $\mathrm{Leu}^{11}$ $\mathrm{Val}^{12}, \mathrm{Gln}^{4}-\mathrm{His}^{5}$ and a minor cleavage site at $\mathrm{Leu}^{17}-\mathrm{Val}^{18}$ in the oxidized insulin $\mathrm{B}$ chain with the proteinase were similar to those reported in the studies of subtilisin Carlsberg (EC 3.4.21.14) at the enzyme substrate ratio (e/s) of 1:980 by Johansen et al. ${ }^{11)}$ The proteinase did not split the $\mathrm{Tyr}^{16}-\mathrm{Leu}^{17}$ and $\mathrm{Tyr}^{26}$ $\mathrm{Thr}^{27}$ bonds in the oxidized insulin $\mathrm{B}$ chain, which are known cleavage sites by subtilisin Carlsberg.

Major cleavage sites at $\mathrm{Leu}^{15}-\mathrm{Tyr}^{16}$ and $\mathrm{Phe}^{24}-\mathrm{Phe}^{25}$ and minor sites at $\mathrm{Leu}^{11}-\mathrm{Val}^{12}$ and $\mathrm{Leu}^{17}-\mathrm{Val}^{18}$ in the oxidized insulin $\mathrm{B}$ chain with the proteinase were similar to those reported in the studies of $S$. cerevisiae proteinase $\mathrm{B}$ at $25^{\circ} \mathrm{C}$ at a ratio of 500:1 (mol insulin B chain/mol proteinase B). ${ }^{15}$ )

The single $\mathrm{SH}$ residue of the proteinase is essential for catalysis, as shown by inhibition studies with $p$-chloromercuribenzoate. ${ }^{3)}$ Inhibition of the proteinase by DFP indicates that in addition to the sulfhydryl residue ${ }^{3)}$ a serine residue $^{2)}$ is also essential for the catalysis. The reaction of the serine residue with DFP is blocked in the presence of $p$ chloromercuribenzoate, suggesting that the serine and cysteine residues are located close together in the proteinase. ${ }^{2,3)}$ Similar observations are reported with $S$. cerevisiae proteinase B. ${ }^{15,16)}$

\section{REFERENCES}

1) K. Mizusawa, E. Ichishima and F. Yoshida, Agric. Biol. Chem., 28, 884 (1964).

2) K. Mizusawa and F. Yoshida, J. Biol. Chem., 247, 6978 (1972).

3) K. Mizusawa and F. Yoshida, J. Biol. Chem., 248, 4417 (1973).

4) N. Tanaka, M. Takeuchi and E. Ichishima, Biochim. Biophys. Acta, 485, 406 (1977).

5) K. Mizusawa, E. Ichishima and F. Yoshida, Appl. Microbiol., 17, 366 (1969).

6) E. Ichishima, Biochim. Biophys. Acta, 258, 274 (1972).

7) H. Frankel-Conrat, J. I. Harris and A. L. Levy, "Methods in Biochemical Analysis," Vol. II, ed. by D. Glick, Interscience, New York, 1955, pp. $359 \sim 425$.

8) W. R. Gray, Methods Enzymol., 25, 121 (1972).

9) I. Schechter and A. Berger, Biochem. Biophys. Res. Commun., 27, 157 (1967).

10) A. M. J. Blow and A. J. Barrett, Biochem. J., 161, 17 (1977).

11) J. T. Johansen, M. Ottesen, I. Svendsen and G. Wybrandt, Compt. Rend. Trav. Carlsberg, 36, 365 (1968).

12) K. Morihara and H. Tsuchiya, Arch. Biochem. Biophys., 129, 620 (1969).

13) Y. Narahashi and K. Yoda, J. Biochem., 73, 831 (1973).

14) T. Nakanishi and K. Yamamoto, Agric. Biol. Chem., 38, 2391 (1974).

15) E. Kominami, H. Hoffschute, L. Leuschel, K. Maier and H. Holzer, Biochim. Biophys. Acta, 661, 136 (1981).

16) E. Kominami, H. Hoffschlte and H. Holzer, Biochim. Biophys. Acta, 661, 124 (1981). 